\author{
Maciej Kronenberg \\ Uniwersytet Łódzki \\ Katedra Geografii Miast i Turyzmu \\ 90-142 Łódż, ul. Kopcińskiego 31 \\ tel. (0-42) 6354675 \\ mkronenberg@geo.uni.lodz.pl
}

\section{TEORETYCZNE I RZECZYWISTE OBSZARY PENETRACJI TURYSTYCZNEJ NA TERENIE ŁODZI}

\section{THEORETICAL AND ACTUAL TOURISM PENETRATION AREAS IN ŁÓDź}

Zarys treści: Celem autora artykulu jest porównanie teoretycznych i rzeczywistych obszarów penetracji turystycznej na przykladzie Lodzi. Na podstawie przeprowadzonego badania autor wnioskuje na temat możliwości wykorzystania teoretycznych obszarów penetracji w analizie rozwoju przestrzeni penetracji turystycznej.

Słowa kluczowe: przestrzeń turystyczna, przestrzeń penetracji turystycznej, Lódż.

Łódź, mimo posiadania praw miejskich od blisko 600 lat, ukształtowała się jako duży organizm miejski w ciągu zaledwie dwóch ostatnich stuleci. Poza bardzo nielicznymi obiektami, tkanka miejska wytworzyła się dopiero w XIX i XX w. Przestrzeń miejska kształtowała się tutaj bardzo gwałtownie, podlegając istotnym zmianom. Równocześnie przez wiele lat Łódź traktowana była jako miasto przemysłowe i nieatrakcyjne turystycznie. W drugiej polowie XX w. pogląd ten zaczął ulegać zmianie. Odkryte zostało piękno architektury XIX-wiecznej, w tym również przemysłowej. Zaczyna doceniać się unikatowe w skali Polski zalożenie urbanistyczne z XIX w., a także zachowane $w$ prawie niezmienionym kształcie kompleksy zabudowy z tego okresu (WILUŚ 1998, KACZMAREK 1998). To co dotychczas uważane było za turystycznie nieatrakcyjne, zaczęło przyciagać turystów. W sposób znaczący powiększyla się (i nadal powiększa) przestrzeń turystyczna miasta.
Abstract: The aim of the article is to compare theoretical and actual tourism penetration areas using the example of Lodz. On the basis of his research, the author draws conclusions regarding the use of theoretical penetration areas in an analysis of tourism penetration space development.

Key words: tourism space, tourism penetration space, Łódż.

Despite having municipal rights for nearly 600 years, Łódź became a large urban centre only in the last two centuries. Apart from a very few buildings, the urban fabric took shape in the $19^{\text {th }}$ and $20^{\text {th }} \mathrm{c}$. when the urban space developed very rapidly and underwent significant changes. Łódź was seen as an industrial and unattractive city for many years but in the second half of the $20^{\text {th }} \mathrm{c}$. this opinion began to change. The beauty of the $19^{\text {th }} \mathrm{c}$. architecture, including the industrial, was rediscovered and gradually the value of the unique and almost unchanged building complexes from the $19^{\text {th }}$ c. started to be appreciated (WILUŚ 1998, KACZMAREK 1998). What had earlier been considered unattractive from a tourist point of view, started to attract them; the tourism space of the city enlarged and is still expanding. 


\section{OBSZARY PENETRACJI TURYSTYCZNEJ}

Obszary penetracji turystycznej (obiekty powierzchniowe, liniowe i punktowe) stanowią fragment przestrzeni turystycznej, dlatego przed przystapieniem do definiowania takich obszarów, konieczne jest wyjaśnienie, czym jest sama przestrzeń turystyczna. Szezegółowego przeglądu definicji tego pojęcia dokonała BRÓDKA (2004), wobec tego autor zrezygnowal $z$ dokonywania podobnej charakterystyki, przyjmując za WARSZYŃSKA i JACKOWSKIM (1979), że ,przestrzeń turystyczna jest to część przestrzeni geograficznej i społeczno-ekonomicznej, w której zachodzą zjawiska turystyczne". Konieczne jest przy tym podkreślenie dwóch istotnych cech przestrzeni turystycznej: funkcjonalności oraz dynamizmu (zmienności w czasie).

Jednym z typów przestrzeni turystycznej, wyróżnionym przez LISZEWSKIEGO (1995, 1999), jest przestrzeń penetracji turystycznej. Samo określenie ,penetracja”, pochodzące z łaciny (penetratio), oznacza m.in. docieranie dokądś w celach badawczych, zagłębianie się czy wnikanie w coś (KOPALIŃSKI 1978). LISZEWSKI (1995) zjawisko penetracji turystycznej określił jako „formę ruchu turystycznego o znacznej skali i rozmiarach, której motywem są cele poznawcze, realizowane najczęściej przez działalność krajoznawcza, lub krótkotrwały wypoczynek, najczęściej bez noclegów". Pojęcie przestrzeni penetracji turystycznej (w obrębie miasta) tlumaczył jako „te fragmenty przestrzeni miejskiej”, które „są najczęściej i przez największą liczbę turystów penetrowane, a celem tej penetracji jest ich poznanie" (LISZEWSKI 1999). Zaliczone tu zostaly przede wszystkim centra historyczne, obiekty zabytkowe i sakralne, muzea, cmentarze, punkty widokowe oraz ogrody zoologiczne i botaniczne. Przestrzeń penetracji jest główną przestrzenią turystyczną w miastach, ponieważ większość odwiedzających w pierwszej kolejności chce zobaczyć obiekty historyczne i zabytkowe (uznawane powszechnie za atrakcyjne). Ważne w definiowaniu przestrzeni penetracji jest również to, że jest ona na ogół podzielona na szereg niewielkich obszarów lub pojedynczych obiektów. W dalszej części pracy przestrzeń penetracji turystycznej jest traktowana zgodnie $z$ definicją S. Liszewskiego.

Praca LISZEWSKIEGO (1999) była próbą przedstawienia przemian przestrzeni turystycznej Ło-

\section{TOURISM PENETRATION AREAS}

Tourism penetration areas (surface, linear and point) are a part of tourism space, therefore, before they are defined, it is necessary to explain what tourism space itself is. A detailed review of definitions has been made by BRODKA (2004), thus the author did not carry out a similar task and assumed, after WARSZYŃSKA \& JACKOWSKI (1979), that 'tourism space is a part of geographical and socio-economic space in which tourism phenomena occur.' Two important features of tourism space need to be stressed here: functionality and dynamism (variability in time).

One of the tourism space types, according to LISZEWSKI (1995, 1999), is tourism penetration space. The very word 'penetration' is of Latin origin (penetratio) and means, among other things, 'reaching into somewhere for research', 'immersing in something' (KoPALIŃSKI 1978). LISZEWSKI (1995) described the phenomenon of tourism penetration as 'a large scale form of tourism whose aims are cognitive, achieved usually through a trip or a short visit, most often without staying somewhere overnight'. The notion of tourism penetration space (within a city) was explained as those parts of urban space which are penetrated most frequently and by the largest number of tourists, and the aim of this penetration is to learn something about them' (LISzEwsKI 1999). This includes above all historical centres, monuments, churches, museums, cemeteries, panorama viewing spots, and zoological and botanical gardens. Penetration space is the main tourism space in cities, because the majority of visitors want first to see the historical buildings and monuments commonly considered the most attractive. When defining penetration space it is also important to remember that it is usually divided into several smaller areas or single sites. In this article tourism penetration space is treated according to Liszewski's definition. 
dzi, w tym glównie przestrzeni penetracji (jako najdłużej funkcjonującej), w której autor posłużył się tzw. metoda przewodnikową, polegającą na analizie przewodników turystycznych z różnych okresów rozwoju miasta. W ten sposób wydzielone zostały trzy fazy tworzenia się przestrzeni turystycznej w Łodzi: do II wojny światowej, okres od 1939 do $1970 \mathrm{r}$. oraz okres następujący po 1970 r. Tak jak zmieniała się ogólna przestrzeń turystyczna, tak również zmianom (rozwojowi) podlegala przestrzeń penetracji. Cechą charakterystyczną tej ostatniej jest jej silna koncentracja w centrum miasta (w granicach administracyjnych z 1840 r.). Widoczna jest również rola glównej ulicy miasta, czyli ulicy Piotrkowskiej, w tworzeniu tego typu przestrzeni.

Obszarami penetracji turystycznej, w świetle przedstawionych definicji, są zatem miejsca i obiekty odwiedzane przez turystów, kierujących się motywem poznawczym. Autor wyróżnił w tytule pracy obszary rzeczywiste i teoretyczne penetracji. Pojęcie rzeczywistych obszarów jest dość oczywiste i oznacza tereny rzeczywiście odwiedzane przez turystów chcących poznać najciekawsze i najważniejsze ich zdaniem miejsca w mieście. Teoretyczne obszary penetracji autor traktuje jako te, które posiadają walory turystyczne (krajoznawcze), niekoniecznie jednak generują ruch turystyczny. W ten sposób, jeżeli przyjąć, że teoretyczne obszary tworzą teoretyczną przestrzeń turystyczną (penetracji), a rzeczywiste przestrzeń rzeczywista, widoczna jest analogia do pojęć zaproponowanych przez WŁODARCZYKA (1999). Autor ten dokonal podziału przestrzeni turystycznej na: rzeczywista, potencjalną oraz nieturystyczna. Przestrzeń rzeczywista to taka, w której „zachodzą zjawiska turystyczne”, natomiast potencjalna została zdefiniowana jako ,spełniająca warunki szeroko rozumianej atrakcyjności turystycznej, jednak obecnie nie wykorzystywana do podejmowania aktywności turystycznej, np. ze względu na brak zagospodarowania turystycznego lub dostępności obszaru”. Różnica w podejściu polega więc na tym, że przestrzeń potencjalna może dopiero stać się przestrzenią rzeczywistą (w przyszłości), a przestrzeń teoretyczna może być tożsama z przestrzenią rzeczywistą już w tej chwili (jeżeli wykazana zostanie obecność ruchu turystycznego).
LISZEWSKI (1999) attempted to present changes in the tourism space of Łódz, mainly to penetration space (as that existing longest). He used the 'guide method', an analysis of tourism guides from different periods of the city's development. In this way three phases in the creation of tourism space in Łódż were established: before World War II, between 1939 and 1970, and after 1970. The general tourism space, as well as penetration space, were changing simultaneously. A characteristic feature of the latter is its strong concentration in the city centre (within the administrative borders of 1840). It is also easy to observe the leading role of the city's main street, Piotrkowska, in the creation of penetration space.

In the light of the definitions presented, places of tourism penetration are sites visited by tourists with a cognitive motivation. The title of the article contains notions of actual and theoretical penetration areas; the notion of an actual area is quite obvious and signifies an area which is actually visited by tourists wanting to see, in their opinion, the most interesting and important places in the city. The theoretical penetration areas are those which possess tourism assets, but do not generate tourism. Assuming that theoretical areas create a theoretical tourism penetration space and actual ones create an actual space, it can be observed that there is an analogy to the notions proposed by WŁODARCZYK (1999). He divided tourism space into actual, potential and non-tourism. The actual space is the one in which 'tourism phenomena occur', while the potential space was defined as one which 'meets the conditions of tourism attractiveness, in the broad sense of the term, but is not currently used for tourism purposes due to, for example, a lack of tourism infrastructure or accessibility.' The difference in approach then consists in the fact that a potential space may become an actual space in the future, and the theoretical space may become identified with the actual at the present moment (provided the occurrence of tourism is proved). 


\section{TEORETYCZNE OBSZARY PENETRACJI ŁODZI}

W pracy autor podjął się porównania teoretycznych i rzeczywistych obszarów penetracji turystycznej na przykładzie Łodzi. Analiza rzeczywistych obszarów penetracji przez turystów stanowi dość oczywistą metodę badania przestrzeni turystycznej. Informacje o tym, jakie miejsca turyści odwiedzają, są tutaj najlepszym i najpelniejszym źródłem. Często jednak dotarcie do turystów, w szczególności turystów indywidualnych, jest utrudnione bądź wręcz niewykonalne (dla osiagnięcia odpowiednio wysokiej reprezentatywności badań). Podobnie przedstawia się sytuacja przy badaniu rozwoju przestrzeni turystycznej w czasie. Pozyskiwanie informacji od turystów odnośnie do minionych aktywności turystycznych prowadzić może do wypaczeń spowodowanych ulotnością pamięci ludzkiej. Stąd konieczne jest poszukiwanie alternatywnych metod oceny rozwoju przestrzeni penetracji. Jedną z nich może stanowić analiza teoretycznych obszarów penetracji.

Teoretyczne obszary określone zostały na podstawie oferty lódzkich biur podróży. Przyjęte zostało założenie, że programy wycieczek (oferta) określają jakie obszary miasta są uznawane przez fachowców w zakresie turystyki (w osobach pracowników biur podróży) za atrakcyjne i godne zaprezentowania przybywającym turystom.

Za łódzkie biura podróży uznane zostały wszystkie podmioty gospodarcze posiadające licencję touroperatorską i będace zarejestrowane w Łodzi. Biur takich bylo $89^{1}$ (stan na 15 XI 2005).

\section{THEORETICAL PENETRATION AREAS OF ŁÓDŹ}

The author has attempted to compare theoretical and actual tourism penetration areas using the example of Łodż. The analysis of the "actual area of tourism penetration' is a fairly obvious method of examining tourism space and information regarding places visited by tourists is the best and most reliable source. However, reaching tourists, particularly individual ones in order to achieve sufficiently representative data, is sometimes difficult or even impossible. A similar situation occurs when studying the development of tourism space across time as obtaining information from tourists regarding their past tourism activity may lead to inaccuracies caused by the unreliability of human memory. Therefore it is necessary to seek alternative methods of evaluating the development of penetration space. One of them could be an analysis of theoretical penetration areas.

The theoretical areas were established on the basis of the offer of Łódz travel agencies. It was assumed that excursion itineraries would show which parts of the city are considered by tourism specialists to be attractive and worth presenting to tourists. Łódź travel agencies are those firms (891) which have a tour-operating licence and are registered in Łódź $\left(15^{\text {th }}\right.$ November 2005). However, the analysis
T a b e l a I. Tematy programów „łódzkich" w ofercie biur podróży

\begin{tabular}{|c|l|c|}
\hline $\mathrm{Nr}$ & \multicolumn{1}{|c|}{ Temat } & $\begin{array}{c}\text { Liczba biur oferujacych } \\
\text { dany program }\end{array}$ \\
\hline 1 & Łódź żydowska & 3 \\
\hline 2 & Łódź wielokulturowa & 2 \\
\hline 3 & Łódź przemysłowa & 2 \\
\hline 4 & Ulica Piotrkowska & 2 \\
\hline 5 & Łódzkie pałace & 2 \\
\hline 6 & Łódż w pigułce & 2 \\
\hline 7 & Łódź filmowa & 2 \\
\hline 8 & Łódź artystyczna & 1 \\
\hline 9 & Łódź niemiecka & 1 \\
\hline 10 & Secesja w Łodzi & 1 \\
\hline
\end{tabular}

Z r o d † o: Opracowanie własne na podstawie oferty łódzkich biur podróży.
T a ble I. Excursion themes offered by Łódż travel agencies

\begin{tabular}{|c|l|c|}
\hline No & \multicolumn{1}{|c|}{ Theme } & $\begin{array}{c}\text { No of agencies to offer } \\
\text { a given itinerary }\end{array}$ \\
\hline 1 & Jewish Łódż & 3 \\
\hline 2 & Multi-cultural Łódź & 2 \\
\hline 3 & Industrial Łódż & 2 \\
\hline 4 & Piotrkowska Street & 2 \\
\hline 5 & Łódź palaces & 2 \\
\hline 6 & Łódż in a nutshell & 2 \\
\hline 7 & Film Łódż & 2 \\
\hline 8 & Artistic Łódź & 1 \\
\hline 9 & German Łódź & 1 \\
\hline 10 & Secession in Łódż & 1 \\
\hline
\end{tabular}

S o u r c e: Author's compilation based on the offer of travel agencies and on the information provided by tourist guides. 
Analizie poddane zostały programy skierowane do turystów przybywających do miasta z zewnątrz. Wykluczone zostały programy biur nastawionych na obsługę łódzkich placówek oświatowych, które autor uznał za element nauki o regionalizmie (podstawą zaszeregowania byl fakt, że w $2005 \mathrm{r}$. biura nie obsłużyly zadnej grupy, oprócz młodzieży z łódzkich szkól).

W toku badań nad ofertą biur podróży utrudnieniem okazal się brak precyzyjnych programów. Jak zaznaczają pracownicy wszystkich biur podróży, programy są jedynie ramowe, uszczególowianie następuje dopiero po konsultacji z klientem. Stąd w ofercie często można odnaleźć stwierdzenia takie, jak np. „zwiedzanie terenu getta” (przy wycieczce tematycznej „Szlakiem żydowskim”) bez precyzowania, jakie obiekty znajdują się na trasie zwiedzania. W wielu biurach w ogóle nie istnieja gotowe szablony programów. Powstają one jedynie na konkretne zamówienie klientów. Dlatego dokładnej analizie poddana została oferta zaledwie trzech łódzkich biur podróży. Posiadają one od czterech do dziewięciu programów tematycznych z zaznaczonymi obiektami. Dokładny wykaz tematów wraz z informacją o tym, w ilu biurach wystapily, znajduje się w tab. I. Łącznie pojawiło się 10 programów wycieczek, przy czym większość z nich (7) powtórzyła się w co najmniej dwóch biurach. Można na tej podstawie zalożyć, że za charakterystyczne dla Łodzi i równocześnie atrakcyjne dla turystów uznane zostały następujące tematy: „Łódź żydowska”, „Łódź wielokulturowa”, ,Łódź przemysłowa”, „Ulica Piotrkowska”, ,Łódzkie palace”, „Łódż w pigułce” oraz „Łódź filmowa”. Obszary uwzględniane w tych programach stanowią najważniejszą część teoretycznych obszarów penetracji turystycznej.

Biorąc pod uwagę fakt, że programy z różnych biur występujące pod taką samą nazwą różnią się w zakresie zwiedzanych obiektów (wyjątek stanowią wycieczki „Łódź filmowa” oraz „Ulica Piotrkowska"), w dalszej analizie będą one traktowane oddzielnie. W ten sposób wydzielonych zostało 16 programów. Przy analizie częstotliwości umieszczania konkretnych obiektów w programach należy odnosić ją zatem do tej właśnie wartości. Przedstawia to tab. II. Znalazl się w niej wykaz wszystkich (28) obiektów uwzględnionych w programach. Warto zwrócić uwagę na kilka cech wymienionych obiektów:

- są to pojedyncze budynki (jak rezydencje, muzea, świątynie), większe obszary (jak Nowe Miasto, Stare Miasto, Księży Młyn, getto), jest również jeden obiekt liniowy (ul. Piotrkowska); concerned only the itineraries offered to tourists arriving from outside the city and those offered by agencies serving Łódż educational institutions were excluded. The author considered them to be an element of regional teaching (such an approach was based on the fact that in 2005 some travel agencies served no other group than those from Łódź schools).

The study of the offer was hindered by a lack of detailed itineraries. According to employees from all travel agencies, itineraries are only very general and actual details are agreed upon with the client. Expressions like "visiting the ghetto' (as part of 'Jewish Trail' excursions) can often be found without precise information about what sites will be visited. In many agencies there are no itinerary patterns at all as they are prepared at a particular client's request. Therefore only the offers of three Lódź travel agencies were analysed in detail with from 4 to 9 themed itineraries with sites singled out. A list of excursion themes and information about the number of agencies in which they appeared can be found in table I and altogether there were 10 itineraries, most of which reappeared in at least one more agency. It can be assumed that the following themes were regarded as characteristic of Łódz and at the same time attractive to tourisms: 'Jewish Łódž', 'Multicultural Łódž', 'Industrial Łódẑ', 'Piotrkowska Street', 'Łódż Palaces', 'Essential Łódź (Łódź $w$ pigutce)', and 'Film Łódź'. The areas included in the above excursions are the most important parts of the theoretical tourism penetration area.

Considering the fact that itineraries from different travel agencies carrying the same name, differ as far as sites visited are concerned (with the exception of the 'Film Łódź' and 'Piotrkowska Street' excursions), they were treated separately in further analysis. In this way 16 itineraries were established. When analysing how often a given site is included, the data refers to these 16 itineraries. Table II presents a list of all 28 sites included and several characteristics listed are worth attention: 
T a b e la II. Rzeczywiste i teoretyczne obszary penetracji turystycznej w Lodzi w 2005 r.

\begin{tabular}{|l|c|c|c|c|}
\hline \multicolumn{1}{|c|}{ Obiekt } & $\begin{array}{c}\text { Liczba } \\
\text { wycie- } \\
\text { czek }\end{array}$ & $\begin{array}{c}\text { Ranga } \\
\text { rzeczy- } \\
\text { wista }\end{array}$ & $\begin{array}{c}\text { Liczba } \\
\text { progra- } \\
\text { mów }\end{array}$ & $\begin{array}{c}\text { Ranga } \\
\text { teore- } \\
\text { tyczna }\end{array}$ \\
\hline Muzeum Historii Miasta & 65 & 1 & 9 & 1 \\
\hline Ulica Piotrkowska & 63 & 1 & 9 & 1 \\
\hline Księży Młyn & 53 & 2 & 7 & 2 \\
\hline Cmentarz żydowski & 23 & 4 & 4 & 5 \\
\hline Muzeum Kinematografii & 23 & 4 & 6 & 3 \\
\hline Stare Miasto & 22 & 5 & 5 & 4 \\
\hline Stacja Radegast & 19 & 5 & 1 & 7 \\
\hline Nowe Miasto & 17 & 5 & 6 & 3 \\
\hline Manufaktura & 15 & 5 & 4 & 5 \\
\hline Rezydencja Księży Młyn & 13 & 6 & 5 & 4 \\
\hline Getto & 13 & 6 & 3 & 6 \\
\hline Stary cmentarz & 10 & 6 & 3 & 6 \\
\hline Szkoła filmowa & 10 & 6 & 2 & 7 \\
\hline Katedra & 9 & 6 & 3 & 6 \\
\hline Muzeum Włókiennictwa & 8 & 6 & 3 & 6 \\
\hline Akademia Muzyczna & 7 & 7 & 2 & 7 \\
\hline Kościół ewangelicki & 7 & 7 & 5 & 4 \\
\hline Willa Kindermanna & 7 & 7 & 1 & 7 \\
\hline Muzeum Sztuki & 7 & 7 & 1 & 7 \\
\hline Wille Richterów & 5 & 7 & 1 & 7 \\
\hline Aleja Gwiazd & 5 & 7 & 4 & 5 \\
\hline Elektrownia secesyina & 5 & 7 & 3 & 6 \\
\hline Kościół św. Józefa & 4 & 7 & - & - \\
\hline Cerkiew św. Aleksandra & 4 & 7 & 2 & 7 \\
\hline Pub Łódż Kaliska & 4 & 7 & - & - \\
\hline Synagoga & 3 & 7 & 3 & 6 \\
\hline Mauzoleum na Radogoszczu & 3 & 7 & - & - \\
\hline Park Szarych Szeregów & 3 & 7 & - & - \\
\hline Nowa Tkalnia" Scheiblera & 2 & 7 & - & - \\
\hline Wille Grohmanów & 2 & 7 & - & - \\
\hline Palmiarnia & 2 & 7 & - & - \\
\hline Uniwersytet Medyczny & 2 & 7 & - & - \\
\hline Kościół NMP & 2 & 7 & - & - \\
\hline Park Żródliska & - & 7 & - & - \\
\hline Pomnik Dekalogu & - & - & 1 & 7 \\
\hline Restauracja Esplanada & - & 1 & 7 \\
\hline Niemieckie Towarzystwo & - & 1 & 7 \\
\hline Spoteczno-Kulturalne & "Beczki Grohmana" & & & \\
\hline
\end{tabular}

Ż ró d to: Opracowanie własne na podstawie oferty biur podróży oraz informacji uzyskanych od przewodników turystycznych.

T a b e la III. Skala rangowania rzeczywistych i teoretycznych obszarów penetracij turystycznej w Łodzi

\begin{tabular}{|c|c|c|c|}
\hline \multicolumn{2}{|c|}{ Obszary rzeczywiste } & \multicolumn{2}{c|}{ Obszary teoretyczne } \\
\hline liczba wycieczek & ranga & liczba programów & ranga \\
\hline $54-65$ & I & $8-9$ & I \\
\hline $42-53$ & II & 7 & II \\
\hline $32-41$ & III & 6 & III \\
\hline $23-31$ & IV & 5 & IV \\
\hline $15-22$ & V & 4 & V \\
\hline $8-14$ & VI & 3 & VI \\
\hline $2-7$ & VII & $1-2$ & VII \\
\hline
\end{tabular}

Ż ód to: Opracowanie własne.
T a ble II. Actual and theoretical tourism penetration areas in Łódż in 2005

\begin{tabular}{|c|c|c|c|c|}
\hline Site & $\begin{array}{c}\text { No of } \\
\text { excursions }\end{array}$ & $\begin{array}{c}\text { Actual } \\
\text { rank }\end{array}$ & $\begin{array}{c}\text { Number of } \\
\text { itineraries } \\
\end{array}$ & $\begin{array}{c}\text { Theoretical } \\
\text { rank }\end{array}$ \\
\hline Museum of Lódź History & 65 & 1 & 9 & 1 \\
\hline Piotrkowska Street & 63 & 1 & 9 & 1 \\
\hline Księży Mlyn (Priest's Mill) & 53 & 2 & 7 & 2 \\
\hline Jewish cemetery & 23 & 4 & 4 & 5 \\
\hline $\begin{array}{l}\text { Museum of Cinemato- } \\
\text { graphy }\end{array}$ & 23 & 4 & 6 & 3 \\
\hline Old Town & 22 & 5 & 5 & 4 \\
\hline Radegast Station & 19 & 5 & 1 & 7 \\
\hline New Town & 17 & 5 & 6 & 3 \\
\hline Manufaktura & 15 & 5 & 4 & 5 \\
\hline Księży Młyn Mansion & 13 & 6 & 5 & 4 \\
\hline Ghetto & 13 & 6 & 3 & 6 \\
\hline Old cemetery & 10 & 6 & 3 & 6 \\
\hline Film School & 10 & 6 & 2 & 7 \\
\hline Cathedral & 9 & 6 & 3 & 6 \\
\hline $\begin{array}{l}\text { Museum of Textile } \\
\text { Industry }\end{array}$ & 8 & 6 & 3 & 6 \\
\hline Music Academy & 7 & 7 & 2 & 7 \\
\hline Evangelical Church & 7 & 7 & 5 & 4 \\
\hline Kindermann Villa & 7 & 7 & 1 & 7 \\
\hline Museum of Art & 7 & 7 & 1 & 7 \\
\hline Richter Villas & 5 & 7 & 1 & 7 \\
\hline 'Avenue of Stars' & 5 & 7 & 4 & 5 \\
\hline Secessionist Power Plant & 5 & 7 & 3 & 6 \\
\hline St. Joseph Church & 4 & 7 & - & - \\
\hline $\begin{array}{l}\text { St. Alexander Orthodox } \\
\text { Church }\end{array}$ & 4 & 7 & 2 & 7 \\
\hline Łódż Kaliska Pub & 4 & 7 & - & - \\
\hline Synagogue & 3 & 7 & 3 & 6 \\
\hline Radogoszcz Mausoleum & 3 & 7 & - & - \\
\hline Szarych Szeregów Park & 3 & 7 & - & - \\
\hline $\begin{array}{c}\text { Scheibler's 'New weaving } \\
\text { mill' (Nowa Tkalnia) }\end{array}$ & 2 & 7 & - & - \\
\hline Grohman Villas & 2 & 7 & - & - \\
\hline Palm Garden & 2 & 7 & - & - \\
\hline Medical University & 2 & 7 & - & - \\
\hline $\begin{array}{l}\text { Church of the Blessed } \\
\text { Virgin Mary }\end{array}$ & 2 & 7 & - & - \\
\hline Żródliska Park & 2 & 7 & - & - \\
\hline Decalogue Monument & - & - & 1 & 7 \\
\hline 'Esplanada' Restaurant & - & - & 1 & 7 \\
\hline $\begin{array}{l}\text { German Socio-Cultural } \\
\text { Society }\end{array}$ & - & - & 1 & 7 \\
\hline 'Grohman Barrels' & - & - & 1 & 7 \\
\hline
\end{tabular}

S o u r c e: Author's compilation based on the offer of the travel agencies and on the information provided by tourist guides.

Ta ble III. The ranking of actual and theoretical tourism penetration areas in Łódź

\begin{tabular}{|c|c|c|c|}
\hline \multicolumn{2}{|c|}{ Actual areas } & \multicolumn{2}{c|}{ Theoretical areas } \\
\hline no of excursions & rank & no of itineraries & rank \\
\hline $54-65$ & I & $8-9$ & I \\
\hline $42-53$ & II & 7 & II \\
\hline $32-41$ & III & 6 & III \\
\hline $23-31$ & IV & 5 & IV \\
\hline $15-22$ & V & 4 & V \\
\hline $8-14$ & VI & 3 & VI \\
\hline $2-7$ & VII & $1-2$ & VII \\
\hline
\end{tabular}


- obiekty pojawiające się w programach polożone są przede wszystkim w centrum miasta (20 obiektów w obrębie granic miasta z 1840 r., wszystkie obiekty w granicach łódzkiej kolei obwodowej);

- w wykazie dominują obiekty powstałe w XIX i na początku XX w., bardzo nieliczne są obiekty późniejsze;

- wśród obiektów można wyróżnić kilka typów miejsc: dawne rezydencje przemysłowców (9), świątynie, miejsca kultu i cmentarze (6), obiekty poprzemysłowe (5), pomniki (3), założenia urbanistyczne (2) oraz inne (3);

- brak wśród obiektów miejsc wypoczynku i rekreacji, zwlaszcza obszarów zielonych (parki, las miejski, ogród botaniczny czy ogród zoologiczny).

Zastanawiający jest fakt braku obszarów zielonych w programach przeznaczonych dla turystów. Oznaczać to może brak świadomości odnośnie do atrakcyjności tych miejsc, jak również pogląd, że przybywający do miasta nastawieni są przede wszystkim na poznanie obiektów związanych $\mathrm{z}$ dziedzictwem kulturowym antropogenicznym.

Warte porównania z przedstawionymi wynikami są również rezultaty badań WITKOWSKIEJ (1995). Na potrzeby określenia percepcji przestrzeni turystycznej Lodzi przeprowadzila ona badanie ankietowe na próbie 250 mieszkańców miasta. Jedno z pytań dotyczyło wymienienia obiektów, które respondent pokazałby gościom przyjeżdżającym z zewnątrz. Najczęściej wskazywano na pałac I. Poznańskiego (obecnie Muzeum Historii Miasta Lodzi - 17,4\%), Teatr Wielki $(10,1 \%)$, ulicę Piotrkowską $(9,6 \%)$, rezydencję Księży Młyn (8\%), Instytut Centrum Zdrowia Matki Polki (6,5\%), Lagiewniki $(6 \%)$ oraz Biała Fabrykę (obecnie Centralne Muzeum Włókiennictwa $-4,5 \%)$.

Jeżeli uznamy, że teoretyczna przestrzeń turystyczna pokrywa się z przestrzenią turystyczną w percepcji mieszkańców, to wyniki obydwu typów badań możemy porównywać. Widoczne staje się, że przeciętni mieszkańcy inaczej postrzegają atrakcyjność Łodzi niż specjališci z dziedziny turystyki (pracownicy biur podróży). O ile część miejsc się powtarza (Muzeum Historii Miasta, ul. Piotrkowska, rezydencja Księży Młyn czy Muzeum Włókiennictwa), to mieszkańcy Łodzi uwzględniali również współczesne obiekty użyteczności publicznej (teatr, szpital), jak również tereny zielone (Las Lagiewnicki). Fakt, że pomię-
- there are single buildings (e.g. residences, museums, shrines) and larger areas (e.g. the New Town (Nowe Miasto), the Old Town (Stare Miasto), Księzy Mtyn (Priest's Mill), the ghetto). There is also one linear site (Piotrkowska Street);

- the sites are mostly located centrally (20 sites within the city borders of 1840 , all sites within the borders of Lódż's encircling railways)

- the list is dominated by those built in the $19^{\text {th }}$ and early $20^{\text {th }}$ c.; there are very few later buildings;

- several types can be distinguished: former residences of factory owners (9); shrines and cemeteries (6); post-industrial sites (5); monuments (3); planned urban complexes (2); and others (3);

- the list lacks recreational sites, especially green areas (parks, municipal forest, botanical or zoological gardens).

It is interesting that there are no green areas included in the itineraries for tourists. This can mean that the attractiveness of such places has not been yet acknowledged or that visitors to Łodź are oriented mainly towards visiting places connected with the cultural and anthropogenic heritage.

The results presented above are worth comparing with those obtained by WrTKOWSKA (1995) who for the purpose of defining the perception of Łódż tourism space conducted a survey among 250 inhabitants. One question concerned the places the respondent would show to visitors arriving from outside the city. The most frequent choices were the Poznański Palace (currently the Museum of Łódź History $17.4 \%$ ), the Grand Theatre (10.1\%), Piotrkowska Street (9.6\%), Księży Mtyn (Priest's Mill) (8\%), the Polish Mothers' Memorial Hospital - Research Institute (Instytut Centrum Zdrowia Matki Polki) (6.5\%), Łagiewniki Forest $(6 \%)$ and the White Factory (Biata Fabryka - currently the Central Museum of the Textile Industry) - (4.5\%).

If we assume that theoretical tourism space overlaps with actual tourism space in the perception of the inhabitants, then we can compare the results of both types of study. It becomes obvious that the average inhabitant perceives the attractive- 
dzy okresem prowadzenia poszczególnych badań minẹlo ok. 10 lat, zmniejsza możliwości porównawcze wyników. Jest to spowodowane przede wszystkim udostępnieniem szeregu miejsc atrakcyjnych dla turystów (np. Manufaktura czy secesyjna elektrownia), jak również dużymi przemianami w postrzeganiu atrakcyjności Lodzi.

\section{RZECZYWISTE OBSZARY PENETRACJI LODZI}

W celu opisania rzeczywistych obszarów penetracji na terenie Lodzi, przeprowadzone zostało badanie wśród przewodników lódzkich. Dotyczylo ono wycieczek zrealizowanych przez nich w $2005 \mathrm{r}$.

Osób posiadających licencję przewodnika miejskiego łódzkiego jest obecnie (stan na listopad 2005) $170^{2}$. Aktywnych na polu przewodnictwa jest jednak znacznie mniej. Autor na podstawie informacji uzyskanych w łódzkich biurach podrózy oraz Centrum Informacji Turystycznej (CIT) oszacowal tę liczbę na 40 osób. Badaniem ankietowym objęte zostały 34 osoby: współpracujące z lódzkimi biurami podróży (18 osób) oraz z CIT (16 osób). Zgodę na udzial w badaniach wyrazito jedynie 20 osób.

Najważniejszym elementem badania była analiza wycieczek przeprowadzonych przez przewodników w okresie od stycznia do listopada 2005 r. Pod uwagę brane były jedynie wycieczki organizowane dla osób spoza Łodzi. W ten sposób wykluczone zostały imprezy organizowane dla szkół lódzkich (m.in. kilkadziesiąt wycieczek „Szlakiem niemieckim" związanym z obchodzonym w Lodzi Rokiem Krajów Obszaru Języka Niemieckiego), a także dla wszystkich mieszkańców Łodzi (akcje „Poznaj swoje miasto” organizowane przez Urząd Miasta Łodzi). Taka selekcja materiału związana była z głównym celem badania, czyli analizą przestrzeni penetracji turystycznej Łodzi użytkowanej przez turystów przyjeżdżających z zewnątrz. W ten sposób $\mathrm{z}$ ponad 150 wycieczek wymienionych w ankietach, analizie poddano 104. Realizowane byly one przez 17 przewodników.

Krótka charakterystyka uwzględnianych grup znajduje się w tab. IV. Ogólem w wycieczkach uczestniczyło ponad 1800 osób, reprezentujących ok. 30 narodowości. Najczęściej pojawiali się w Łodzi Amerykanie, Niemcy, Francuzi, Brytyjczycy oraz obywatele Izraela. Przecięt- ness of Łódż differently from tourism specialists (employees of travel agencies). Although some sites were mentioned repeatedly (the Museum of Łódż History, Piotrkowska Street, Księzy Mtyn or the Museum of Textile Industry), Łódż inhabitants also included contemporary buildings in public use (theatre and hospital), as well as green areas (Łagiewniki Forest). The fact that 10 years elapsed between individual studies makes the comparison more limited. In the meantime several attractive sites have become available to tourists (e.g. Manufaktura or the secessionist power plant) while the perception of the attractiveness of Łódź has changed considerably.

\section{ACTUAL PENETRATION AREAS OF ŁóDŹ}

In order to describe the actual penetration areas in Łódż a survey was carried out among Lódź tourist guides concerning excursions run by them in 2005. There are currently $170^{2}$ with a guide's licence in Łódź (November 2005) but active guides are not as numerous. On the basis of information obtained in Łódż travel agencies and from the Tourist Information Centre, the author estimated their number at 40. The survey included 34 , some of them cooperating with Łódź travel agencies (18) and some with the Tourist Information Centre (16). Only 20 agreed to take part in the study.

The most important element of the study was an analysis of excursions run by the tourist guides between January and November in 2005. Only excursions organized for tourists from outside Łódź were considered and schools excursions were excluded (e.g. a number entitled 'Following the German Trail', connected with the 'Year of German Speaking Countries'), as well as excursions for Łódż inhabitants ('Know your City' events organized by the City Council). Such a selection of material resulted from the main object of the study, i.e. the analysis of the tourism penetration space in Łódź used by tourists from outside the city. Out of over 150 excursions mentioned in the questionnaires, only 104 were analysed. They were run by 17 tourist guides. 
nie w grupie znajdowalo się 18 osób, przy czym widoczne są duże rozbieżności w zależności od krajów pochodzenia. Zdecydowanie najliczniejsze byly grupy polskie.

T a b e I a IV. Charakterystyka grup turystycznych odwiedzających Łódż w 2005 r. (uwzględnionych w badaniu)

\begin{tabular}{|l|c|c|}
\hline \multicolumn{1}{|c|}{ Narodowość } & Liczba grup & $\begin{array}{c}\text { Srednia liczba osób } \\
\text { w grupie }\end{array}$ \\
\hline Ogótem & 104 & 18,2 \\
\hline Mieszana & 32 & 15,5 \\
\hline Polska & 29 & 29,0 \\
w tym: & 7 & 33,4 \\
cała Polska & 5 & 45,0 \\
woj. łódzkie & 4 & 20,5 \\
Poznan & 3 & 29,3 \\
Warszawa & 10 & 23,3 \\
\hline pozostałe & 7 & 18,6 \\
\hline USA & 7 & 16,6 \\
\hline Niemcy & 5 & 5,2 \\
\hline Francja & 4 & 17,5 \\
\hline W. Brytania & 5 & 7,8 \\
\hline Izrael & 15 & 8,7 \\
\hline Pozostałe & & \\
\hline
\end{tabular}

Ż ród to: Opracowanie własne na podstawie informacji uzyskanych od przewodników turystycznych.

Ogółem przewodnicy wymienili 54 obiekty odwiedzone podczas wycieczek w 2005 r. Te z nich, które pojawily się co najmniej dwukrotnie (34), zostaly przedstawione w tab. II. Zdecydowanie najczęściej wskazywano na trzy obiekty: Muzeum Historii Miasta Łodzi, ulicę Piotrkowską oraz Księży Młyn. Każdy z nich pojawił się w ponad polowie wszystkich wycieczek. Obiekty wskazane przez przewodników w dużej części pokrywaly się $\mathrm{z}$ ujętymi $\mathrm{W}$ programach wycieczek. Ich charakterystyka jest zatem zbieżna $\mathrm{z}$ przedstawioną dla teoretycznych obszarów penetracji. Jedyną różnicą jest uwzględnienie przez przewodników obszarów zielonych (dwa parki i palmiarnia).

Obiektom ujętym w tab. II nadano rangi, odpowiadające częstotliwości, z jaką pojawiały się zarówno $\mathrm{w}$ programach biur, jak $\mathrm{i} \mathrm{w}$ zrealizowanych wycieczkach. Skala rangowania przedstawiona została w tab. III. Rangowanie pozwoliło na porównanie obydwu statystyk i ocenę podobieństw. Spośród wszystkich 38 obiektów (34 wymienionych przez przewodników i $28 \mathrm{w}$ programach biur) powtarzało się 24. Wśród nich 13 miało tę samą rangę, a w 6 przypadkach rangi różniły się o wartość 1 . Najwyższa różnica rang
A short description of tourist groups can be found in table IV. All in all, over 1800 participated in the excursions, and they represented 30 nationalities with the majority of foreign visitors being American, German, French, British and Israeli. The average group size was 18, and large differences can be observed as far as the nationalities of participants are concerned. Polish groups were the most numerous.

T a b le IV. Tourist groups visiting Łódź in 2005 (included in the study)

\begin{tabular}{|l|c|c|}
\hline \multicolumn{1}{|c|}{ Nationality } & No of groups & Average no/ group \\
\hline Total & 104 & 18.2 \\
\hline Mixed & 32 & 15.5 \\
\hline Poland & 29 & 29.0 \\
$\quad$ including: & & \\
Poland in general & 7 & 33.4 \\
Łódż Województwo & 5 & 45.0 \\
Poznań & 4 & 20.5 \\
Warsaw & 3 & 29.3 \\
other & 10 & 23.3 \\
\hline USA & 7 & 18.6 \\
\hline Germany & 7 & 16.6 \\
\hline France & 5 & 5.2 \\
\hline Great Britain & 4 & 17.5 \\
\hline Israel & 5 & 7.8 \\
\hline Other & 15 & 8.7 \\
\hline
\end{tabular}

S o u r c e: Author's compilation based on information provided by tourist guides.

In total, the guides pointed to 54 sites visited during excursions in 2005, and those mentioned at least twice (34) are presented in table II. The following three were those mentioned most frequently: the Museum of Łódż History, Piotrkowska Street and Księży Mtyn (Priest's Mill), each appearing in nearly half the excursions. The sites included by the guides largely overlapped with those in excursion itineraries so they are in accordance with the theoretical penetration area. The only difference is the inclusion of green areas by the guides (two parks and the palm house).

Sites in table II were given ranks corresponding to their frequency of occurrence both in the agencies' itineraries and in actual trips. The ranking scale is presented in table III enabling the author to compare both sets of figures and to evaluate the similarities. From all the 38 sites (34 mentioned by the guides and 28 in the 
wyniosła 3 i wystapiła w zaledwie jednym przypadku. Był to kościół ewangelicki, obiekt, który pojawia się często w programach biur podróży (jako sztandarowy przykład łódzkiej wielokulturowości), ale dość rzadko jest odwiedzany przez turystów.

Obiekty uwzględnione w tab. II zostały przedstawione na rys. 1. Widoczna jest znacząca koncentracja obiektów na terenie miasta (wszystkie obiekty w granicach kolei obwodowej). Poza 24 obiektami (które wystapily zarówno w programach biur, jak i w zrealizowanych wycieczkach), wystapiło jeszcze 14, które pojawily się tylko w jednym z tych źródel. Wśród tych ostatnich widoczne jest bardzo duże podobieństwo w rozmieszczeniu. itineraries), 24 reappeared and among these 13 had the same rank, while in 6 cases the ranks differed by just 1 . The biggest difference was 3 which occurred only once in the case of the evangelical church - this often appears in travel agencies' itineraries as a leading example of the multicultural character of Łodź, but is rarely visited by tourists.

Sites in table II are presented in figure 1 and it is easy to observe a considerable concentration in the central area (all sites can be found within the boundaries of Łódż's encircling railways). Apart from 24 sites which appeared both in the agencies' itineraries and in actual trips, there are 14 others which appeared only in one of the two. Among them a high similarity in distribution can be observed.

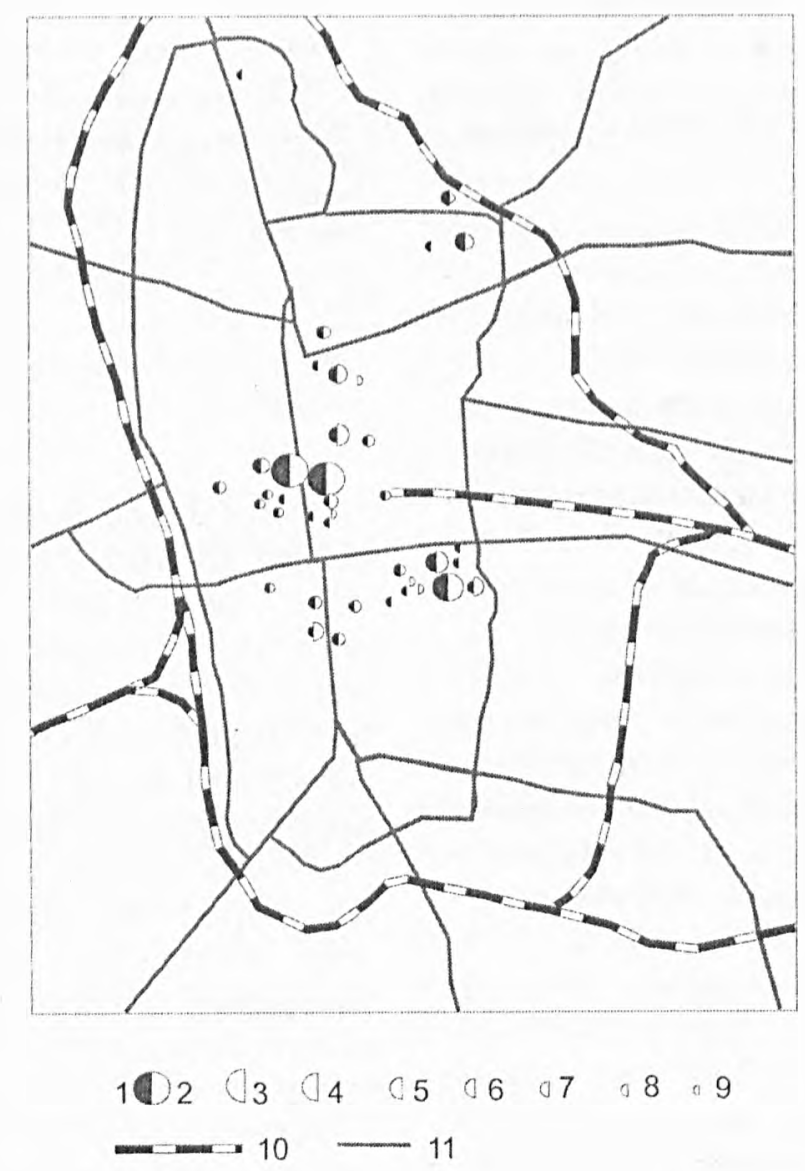

Rys. 1. Przestrzeń penetracji turystycznej Łodzi (ż ró d to: opracowanie własne) Obszary penetracji: 1 - rzeczywiste, 2 - teoretyczne; rangi: 3-I, 4- II, 5- III, $6-I V, 7-V, 8-V I, 9-V I I, 10$ - linie kolejowe, 11 - główne drogi

Fig. 1. Tourist penetration space in Łódż (s o u r c e: author's compilation) Penetration areas: 1 - actual, 2 - theoretical; ranks: $3-I, 4-I I, 5-I I I, 6-I V$, $7-V, 8-V I, 9-V I I, 10$ - railway lines, 11 - main roads 


\section{PODSUMOWANIE}

Celem postawionym przez autora na początku badań było porównanie dwóch rodzajów obszarów penetracji - rzeczywistego i teoretycznego. Wyniki miały dać odpowiedź na pytanie o zasadność wyznaczania teoretycznych obszarów penetracji turystycznej w kontekście wykorzystania ich do analizy rozwoju przestrzeni penetracji turystycznej. Badanie wykazało, że oferta biur podróży w zdecydowanej większości pokrywa się z preferencjami turystów (zarówno pod względem przestrzennym, jak i ilościowym - patrz rys. 1 oraz tab. II). Możliwe jest zatem wnioskowanie o kształcie i rozmiarach przestrzeni penetracji turystycznej na podstawie oferty biur podróży. Uwzględnienie zmian w programach biur podróży na przestrzeni dluższego czasu pozwoliłoby na określenie przemian przestrzeni penetracji turystycznej. Badanie takie traktowane może być jako metoda pośrednia $\mathrm{W}$ analizie rozwoju przestrzeni penetracji turystycznej i stanowić uzupelnienie analizy przewodnikowej zaproponowanej przez LISZEWSKIEGO (1999) na podstawie pracy ŻEBROWSKIEJ (1996).

Konieczne jest jednak zwrócenie uwagi na pewne mankamenty proponowanej metody:

1) ogranicza się ona do określonego typu przestrzeni turystycznej, jakim jest przestrzeń penetracji turystycznej,

2) badanie może być utrudnione w odniesieniu do obszarów szczególnie atrakcyjnych turystycznie (tam gdzie wycieczki organizowane są nie tylko przez lokalnych turoperatorów, ale także inne firmy spoza tego obszaru).

W celu pelnej weryfikacji metody oraz porównania oferty biur podróży z pracą przewodników, konieczne jest także przeprowadzenie pełniejszych badań wśród tych ostatnich. Wyniki zaprezentowane $\mathrm{w}$ pracy dotyczyły jedynie polowy tej grupy zawodowej ( 20 z 40 osób), co mogło zaważyć na jakości otrzymanych rezultatów.

\section{CONCLUSIONS}

The author's aim at the start of the study was to compare two types of penetration area - actual and theoretical. The results were to answer the question of the purpose of establishing theoretical tourism penetration areas in order to study the development of tourism penetration space. The research showed that travel agencies' offers mostly respond to tourists' preferences (both as far as space and quantity are concerned - see figure 1 and table II) so it is possible to draw conclusions regarding the shape and size of tourism penetration space on the basis of this offer. Analysing changes in travel agencies' itineraries over a longer period of time would allow a description of changes in tourism penetration space. Such a study could be treated as an indirect method in the analysis of the development of penetration space and supplement the guide analysis suggested by LiszEWSKI (1999), based on ŻEBROWSKA's (1996) work.

It is necessary, however, to consider certain drawbacks:

1) it is limited to a particular type of tourism space, namely tourism penetration space;

2) research could be difficult as regards the particularly attractive areas (where excursions are organized not only by local tour-operators, but also other firms from outside the areas).

In order to fully verify the method and to compare the offer of travel agencies with guides' work, it is also necessary to carry out more comprehensive research among the latter. The results presented in the article concerned only half of their group (20 out of 40) which could have affected the reliability of the results.

\section{PRZYPISY}

\footnotetext{
'www.turystyka.crz.mg.gov.pl.

${ }^{2}$ Tamże.
}

\section{FOOTNOTES}

\footnotetext{
1 www.turystyka.crz.mg.gov.pl

2 See above.
} 


\section{BIBLIOGRAFIA - BIBLIOGRAPHY}

BRODKA S., 2004, Przestrzen rekreacyjna jako przedmiot badań geograficznych. Badania Fizjograficzne nad Polska Zachodnia, ser. A - Geografia fizyczna, 55, s. 35-51.

KaCZMAREK S., 1998, XIX-wieczne tereny przemystowe to dzi jako element potencjatu turystycznego, "Turyzm”, t. 8, z. 2, s. 85-90.

KOPALIŃSKI W., 1978. Stownik wyrazów obcych $i$ zwrotów obcojęzycznych, Wiedza Powszechna, Warszawa.

Liszewski S., 1995. Przestrzeń turystyczna, „Turyzm”, t. 5, z. 2, s. 87-101.

LiszewsKi S., 1999, Przestrzeń turystyczna miasta (przy kład Łodzi), „Turyzm”, t. 9, z. 1, s. 51-70.

WARSZYŃSKA J., JACKOWSKI A., 1979, Podstawy geografii turyzmu, PWN, Warszawa.
WiLuŚ R., 1998, Wiedza o mieście przemysłowym Łodzi $w$ sivietle analizy przewodników turystycznych, „Turyzm", t. 8, z. 2 .

WITKOWSKA K., 1995, Percepcja przestrzeni turystycznej Łodzi przez jej mieszkańców, maszynopis pracy magisterskiej wykonanej w Katedrze Geografii Miast i Turyzmu UŁ, Łỏdż.

WlodarczYK B., 1999, Przemiany form aktywności turystycznej. Przyktad krawędzi Wyżyny tódzkiej, „Szlakami Nauki", nr 26, LTN, Łódź.

ŻEBrowsKa A., 1996, Obraz turystyczny Łodzi $w$ świetle analizy zawartości treści przewodników, maszynopis pracy magisterskiej wykonanej w Katedrze Geografii Miast i Turyzmu Ut, Lódź. 